\title{
PENERAPAN MODEL PEMBELAJARAN INQUIRI TRAINING PADA MATA PELAJARAN PENJASKES DALAM UPAYA PENINGKATAN KEMAMPUAN KOGNITIF SISWA IV SD NEGERI 101804 GEDUNG JOHOR
}

\author{
Saptariani Br. Purba \\ Surel : fauryhidayati@gmail.com
}

\begin{abstract}
ABSTRAK
Penelitian ini bertujuan untuk meningkatkan kemampuan kognitif siswa pada mata pelajaran penjaskes melalui model pembelajaran inquiri training di kelas IV SD Negeri 101804 Gedung Johor T.P 2015/2016. Subjek penelitian yaitu siswa sebanyak 35 orang siswa. Hasil penelitian menunjukkan pada formatif I 8 orang siswa tuntas, sedangkan kelas tidak tuntas. Pada formatif II tuntas secara individu sebanyak 32 orang siswa, sedangkan kelas tuntas dengan ratarata siklus I dan II adalah 61,71 dan 80 serta persentase ketuntasan klasikal $22,85 \%$ pada siklus I dan $91,42 \%$ pada siklus II. Hasil observer pada siklus I antara lain: memperagakan (33\%), mengerjakan LKS (21\%), bertanya sesama teman (13\%), bertanya kepada guru (13\%), dan yang tidak relevan dengan KBM (22\%) dan data aktivitas siswa menurut pengamatan pada siklus II antara lain: memperagakan (35\%), mengerjakan LKS (24\%), bertanya sesama teman (17\%), bertanya kepada guru (19\%), dan yang tidak relevan dengan KBM (6\%). Dengan demikian model pembelajaran inquiri training dapat meningkatkan kemampuan kognitif siswa pada mata pelajaran penjaskes siswa.
\end{abstract}

Kata Kunci : Aktivitas Belajar, Hasil Belajar, Inquiri Training

\section{PENDAHULUAN}

Dalam mengembangkan

model pembelajaran seorang guru harus dapat menyesuaikan antara model yang dipilihnya dengan kondisi siswa, materi pelajaran, dan sarana yang ada. Oleh karena itu, guru harus menguasai beberapa jenis model pembelajaran agar proses belajar mengajar berjalan lancar dan tujuan yang ingin dicapai dapat terwujud.

Berdasarkan pengalaman guru di SD Negeri 101804 Gedung Johor sampai sekarang masalah yang sering dihadapi dalam mengajarkan mata pelajaran penjaskes di kelas IV adalah kurangnya minat belajar siswa, guru tidak memiliki media untuk mengajar dan kurang tepatnya metode pembelajaran yang digunakan yakni metode ceramah sehingga mengakibatkan siswa sering ribut di dalam kelas dan mengantuk. Kondisi lapangan yang tidak memadai dan alat peraga dalam kegiatan pembelajaran penjaskes yang tidak mendukung menjadi salah satu masalah dalam pembelajaran penjaskes. Mengakibatkan hasil belajar siswa kelas IV tidak mencapai KKM yang dikehendaki. Pengawasan orang tua siswa di rumah juga sangat mempengaruhi aktivitas belajar siswa. Orang tua yang sibuk dalam bekerja mengakibatkan siswa kurang 
terkontrol dalam belajar sehingga terlalu banyak dalam bermain.

Masalah utama dalam pembelajaran penjaskes ialah belum tepatnya penggunaan metode atau model pembelajaran dalam menyampaikan materi pelajaran, yang memenuhi muatan tatanan nilai, agar dapat diinternalisasikan pada diri siswa serta mengimplementasikan hakekat pendidikan nilai dalam kehidupan mereka sehari-hari. Hal ini berkaitan dengan kritik masyarakat terhadap materi pelajaran Penjaskes yang tidak bermuatan nilai-nilai praktis tetapi hanya bersifat politis atau alat indoktrinasi untuk kepentingan kekuasaan pemerintah. Strategi pembelajaran dalam Proses Belajar Mengajar (PBM) terkesan sangat kaku, kurang fleksibel, kurang demokratis, dan guru cenderung lebih dominan. Di samping masih menggunakan model konvensional yang monoton, aktivitas guru lebih dominan daripada siswa, akibatnya guru seringkali mengabaikan proses pembinaan tatanan nilai, sikap, dan tindakan, sehingga mata pelajaran Penjaskes tidak dianggap sebagai mata pelajaran pembinaan warga negara yang menekankan pada kesadaran akan hak dan kewajiban tetapi lebih cenderung menjadi mata pelajaran yang jenuh dan membosankan.

Untuk meminimalkan permasalahan tersebut maka guru harus menggunakan model pembelajaran yang dapat menciptakan suasana belajar yang melibatkan siswa bekerja secara gotong royong yaitu dengan menggunakan model pembelajaran kooperatif. Salah satu model pembelajaran Inquiry Training. Model pembelajaran Inquiry Training memiliki ciri-ciri dapat membangkitkan aktivitas belajar siswa dan memunculkan ketrampilan kooperatif dari siswa.

Berdasarkan uraian di atas, maka peneliti tertarik untuk melakukan suatu penelitian yang berjudul: "Penerapan Model Pembelajaran Inquiri Training Pada Mata Pelajaran Penjaskes Dalam Upaya Peningkatan Kemampuan Kognitif Siswa IV SD Negeri 101804 Gedung Johor".

\section{METODE PENELITIAN}

Penelitian ini dilakukan di SD Negeri 101804 Gedung Johor pada bulan Agustus sampai dengan Desember T.P. 2015/2016. Subjek dalam penelitian ini sebanyak I (satu) kelas yaitu kelas IV SD Negeri 101804 Gedung Johor sebanyak 35 orang.

Penelitian ini menggunakan Penelitian Tindakan Kelas (PTK). PTK adalah suatu bentuk kajian yang bersifat reflektif oleh pelaku tindakan yang dilakukan untuk meningkatkan kemantapan rasional dari tindakan mereka dalam melaksanakan tugas, memperdalam pemahaman terhadap tindakan-tindakan yang dilakukan itu, serta memperbaiki kondisi dimana praktek pembelajaran tersebut dilakukan.

Penelitian Tindakan Kelas (PTK) yaitu penelitian tindakan, maka penelitian ini menggunakan 
model penelitian tindakan dari Kemmis dan Taggart (dalam Arikunto, 2002: 83), yaitu berbentuk spiral dari siklus yang satu ke siklus yang berikutnya. Setiap siklus meliputi planning (rencana), action (tindakan), observation (pengamatan), dan reflection (refleksi). Langkah pada siklus berikutnya adalah perencanaan yang sudah direvisi, tindakan, pengamatan, dan refleksi. Sebelum masuk pada siklus 1 dilakukan tindakan pendahuluan yang berupa identifikasi permasalahan. Prosedur tersebut banyak diacu oleh guru dalam melaksanakan PTK dengan memuat bagan dalam Sani dan Sudiran (2012) sebagai berikut:

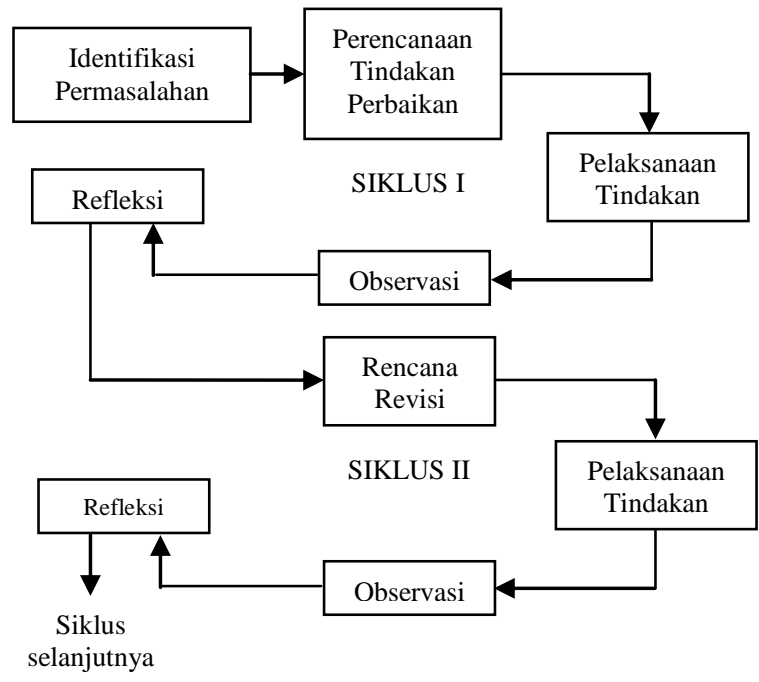

Gambar 1 Siklus dalam Prosedur PTK

Metode analisis data pada penelitian ini digunakan metode deskriptif dengan membandingkan hasil belajar siswa sebelum tindakan dengan hasil belajar siswa setelah tindakan.

Langkah-langkah pengolahan data sebagai berikut:
1. Merekapitulasi nilai pretes sebelum tindakan dan nilai tes akhir siklus I dan siklus II.

2. Menghitung nilai rata-rata atau persentase hasil belajar siswa sebelum dilakukan tindakan dengan hasil belajar setelah dilakukan tindakan pada siklus I dan siklus II untuk mengetahui adanya peningkatan hasil belajar.

3. Penilaian

a. Penilaian aktivitas digunakan rumus sebagai berikut:

$\%$ Aktivitas $=\frac{\text { jumlah skor diperoleh }}{\text { jumlah skor ideal }} \times 100 \%$

b. Data nilai hasil belajar (kognitif) diperoleh dengan menggunakan rumus:

Nilai Siswa $=\frac{\text { Jumlah jawaban benar }}{\text { Jumlah seluruh soal }} \times 100$

c. Nilai rata-rata siswa dicari dengan rumus sebagai berikut:

Keterangan :

$$
\bar{X}=\frac{\sum X}{N}
$$

$$
\begin{aligned}
\bar{X} & =\text { Nilai rata-rata } \\
\Sigma & =\text { Jumlah nilai } X \\
\mathrm{~N} & =\text { Jumlah peserta tes }
\end{aligned}
$$

d. Ketentuan persentase ketuntasan belajar kelas Ketuntasan belajar kelas $=\frac{\sum \mathrm{S}_{\mathrm{b}}}{\mathrm{K}} \times 100 \%$

$\Sigma \mathrm{Sb}=$ Jumlah siswa yang mendapat nilai $\geq 70$ (kognitif). $\Sigma \mathrm{K}=$ Jumlah siswa dalam sampel. 


\section{HASIL DAN PEMBAHASAN}

Sebelum melakukan siklus I peneliti terlebih dahulu mengumpulkan data yang berhubungan dengan kondisi awal siswa. Untuk memperoleh data tersebut, peneliti memberikan ujian pretes yang mencakup seluruh indikator yang akan menjadi bahan ajar untuk 4 KBM (siklus I dan II). Adapun data yang diperoleh seperti pada tabel berikut:

Tabel 1 Distribusi Hasil Pretes

\begin{tabular}{|c|c|c|}
\hline Nilai & Frekuensi & Rata-rata \\
\hline 40 & 2 & \multirow{2}{*}{} \\
\cline { 1 - 2 } 50 & 6 & \multirow{2}{*}{60} \\
\hline 60 & 19 & \\
\hline 70 & 6 & \\
\hline 80 & 2 & \\
\hline Jumlah & 35 & \\
\hline
\end{tabular}

Berdasarkan data di atas hanya satu orang pun siswa mendapat nilai sesuai $\mathrm{KKM}$, dengan ketuntasan klasikal 22,85\%. Nilai tertinggi adalah 80, dan terendah adalah 40 . Berdasarkan data di atas dapat ditarik kesimpulan bahwa siswa tidak mempersiapkan diri sebelum mengikuti pembelajaran di sekolah. Siswa tidak membaca materi yang akan di pelajari di rumah. Siswa hanya mengharapkan penjelasan guru tanpa mencari tau maupun membekali diri. Hal ini menunjukan aktivitas belajar siswa rendah.

\section{Siklus I}

Proses penelitian ini dilakukan dalam dua siklus yang masing-masing siklus terdiri dari 2 kali tatap muka dan 4 tahapan, yaitu: (1) perencanaan tindakan, (2) pelaksanaan tindakan, (3) observasi dan interpretasi, dan (4) analisis dan refleksi serta tindakan perbaikan. Dalam perencanaan telah berhasil disusun sebuah perangkat pembelajaran melalui model pembelajaran inquiry training yang terdiri dari RPP, dan Instrumen tes hasil belajar siswa. Sementara tindakaan perbaikan untuk siklus II direncanakaan setelah berakhirnya siklus I.

a) Data Aktivitas Belajar Siswa

Penilaian aktivitas diperoleh dari lembar observasi aktivitas. Pengamatan dilakukan oleh dua pengamat selama 20 menit kerja kelompok dalam setiap KBM. Dengan pengamatan setiap 2 menit siklus I.

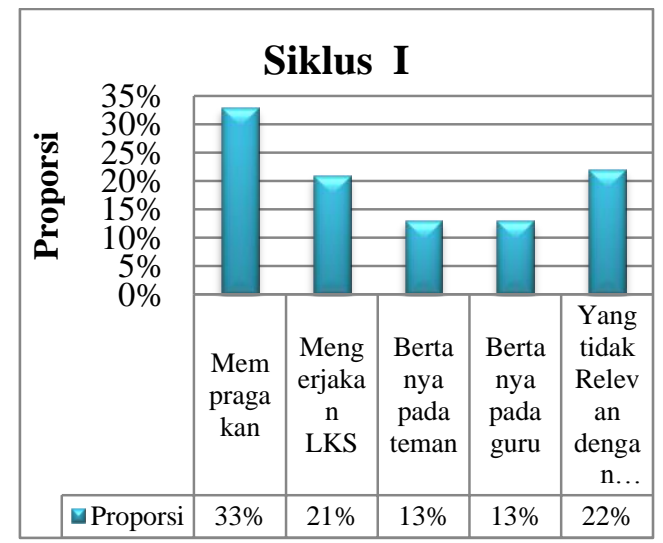

Gambar 2 Grafik Aktivitas Belajar

Siswa Siklus I

b) Data Hasil Belajar Siswa Siklus I

Siklus I dilakukan dengan 2 KBM. Di akhir siklus I siswa diberikan tes belajar. Soal tes tersebut adalah sebagian dari instrumen pada pretes yang mewakili indikator yang 
telah dipelajari. Tes di akhir siklus I ini disebut sebagai formatif I. Dari formatif I diperoleh data yang disajikan dalam Tabel sebagai berikut:

Tabel 2 Distribusi Hasil Formatif I

\begin{tabular}{|c|c|c|}
\hline Nilai & Frekuensi & Rata-rata \\
\hline 40 & 5 & \\
\cline { 1 - 2 } 60 & 22 & \multirow{2}{*}{61,71} \\
\hline 80 & 8 & \\
\hline Jumlah & 35 & \\
\hline
\end{tabular}

Merujuk pada tabel 2, nilai terendah formatif I adalah 40 dan tertinggi adalah 80. Kriteria ketuntasan minimum yang ditetapkan adalah 70 sehingga meskipun nilai rata-rata sebesar 61,71 telah ada siswa yang mancapai ketuntasan namun, 17 orang mendapat nilai dibawah kriteria ketuntasan atau tidak tuntas, dengan demikian ketuntasan klasikal adalah sebesar 22,85\%. Kriteria ketuntasan klasikal yang ditetapkan adalah $85 \%$ siswa memperoleh nilai sama dengan atau di atas KKM. Sehingga nilai ini jauh berada di bawah kriteria keberhasilan sehingga dapat dikatakan KBM siklus I sama sekali tidak berhasil memberi ketuntasan belajar dalam kelas.

\section{c) Refleksi dan Tindakan Perbaikan}

Merujuk pada tabel 2 diatas, hanya $8(22,85 \%)$ siswa yang lulus KKM yang telah ditetapkan. Sedangkan 17 siswa belum mencapai ketuntasan. Rendahnya hasil belajar siklus 1 tidak terlepas dari rendahnya aktivitas belajar pada siklus I. Merujuk tabel 4.2 aktivitas siswa yang paling dominan yakni Mempragakan (33\%), mengerjakan LKS (21\%), bertanya pada teman (13\%), bertanya pada guru (13\%), aktivitas yang tidak relevan dengan KBM (22\%). Berdasarkan refleksi yang peneliti lakukan rendahnya aktivitas dan hasil belajar siswa diakibatkan oleh beberapa hal diantaranya, ketika siswa berdiskusi dalam kelompok banyak kelompok yang terlihat bingung dalam pelaksanaannya. Ada pula yang bingung dengan langkah yang harus dilaksanakan. Sementara beberapa siswa tidak aktif dalam melaksanakan diskusi, siswa tersebut hanya berdiam diri, seolah-olah tidak mau tahu meskipun beberapa ada beberapa siswa yang aktif dalam praktek. Semua kendala-kendala pembelajaran yang muncul pada siklus I disebabkan oleh ketidaksiapan siswa dalam mengikuti proses pembelajaran. Siswa tidak melakukan persiapan dari rumah dengan mempelajari sebagian materi baru yang akan diajarkan. Kemudian yang paling penting adalah siswa tidak terbiasa melakukan pembelajaran dengan model inquiry training dan pembelajaran secara berkelompok. Disaat yang sama guru sebagai peneliti belum mampu memberikan kesimpulan secara cepat untuk memutuskan tindakan perbaikan yang perlu dilakukan.

$$
\text { Untuk menyelesaikan }
$$

kendala-kendala di atas, peneliti berdiskusi dengan teman sejawat peneliti, dan juga tutor dari LPMP dan UNIMED untuk menyusun tindakan perbaikan pada siklus II. 
Berdasarkan refleksi siklus I bebarapa tindakan perbaikan pembelajaran yang dilakukan di siklus II antara lain: peneliti lebih memperhatikan dan mendekati kelompok yang memerlukan bimbingan, Peneliti memberikan tugas rumah tentang materi siklus II kepada siswa sebelum memasuki siklus II agar siswa memiliki cukup persiapan untuk mengikuti proses pembelajaran yang akan di lakukan.

\section{Siklus II}

Pembelajaran siklus II di lakukan setelah peneliti melakukan refleksi dan berdiskusi dengan tutor, teman sejawat (guru mata pelajaran yang sama) kelas IV SD Negeri 101804 Gedung Johor untuk menyusun tindakan perbaikan.

a) Aktivitas Belajar Siswa Siklus II Tabel 4.4 Skor Aktivitas Belajar Siklus II diperoleh dari lembar observasi aktivitas. Pengamatan dilakukan oleh dua pengamat selama 20 menit kerja kelompok dalam setiap KBM. Dengan pengamatan setiap 2 menit. Adapun data aktivitas yang diperoleh pada siklus II sebagai berikut.

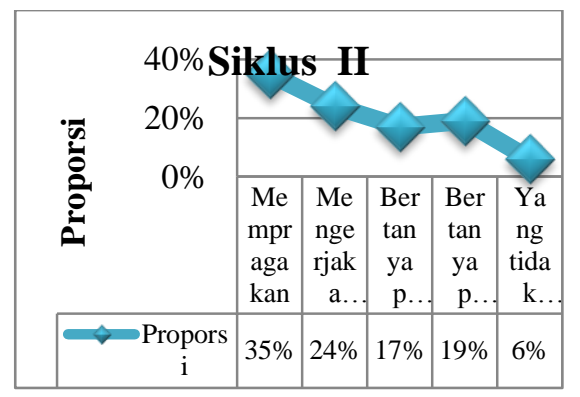

Gambar 3 Grafik Aktivitas Belajar Siswa Siklus II b) Data Hasil Belajar Siswa Siklus II

Setelah berakhirnya

pembelajaran siklus II dilakukan formatif II:

Tabel 3 Distribusi Hasil Formatif II

\begin{tabular}{|c|c|c|}
\hline Nilai & Frekuensi & Rata-rata \\
\hline 40 & 1 & \\
\cline { 1 - 2 } 60 & 2 & \multirow{2}{*}{80} \\
\hline 80 & 28 & \\
\hline 100 & 4 & \\
\cline { 1 - 2 } Jumlah & 35 & \\
\hline \multicolumn{2}{|c|}{ Merujuk pada tabel 3, nilai }
\end{tabular}
terendah untuk formatif II adalah 40 dan tertinggi adalah 100 dengan kriteria ketuntasan minimal 75 . Nilai rata-rata yang diperoleh sebesar 80 nilai ini meningkat dibandingkaan formatif I dan telah tuntas, ketuntasan klasikal hanya mencapai 91,42\%. Mengacu pada kriteria ketuntasan klasikal minimum sebesar $85 \%$ maka nilai ini berada di atas kriteria keberhasilan sehingga dapat dikatakan KBM siklus II juga sudah berhasil memberi ketuntasan belajar dalam kelas.

c) Refleksi dan Tindakan Perbaikan Hasil belajar siswa diakhir siklus II telah mencapai ketuntasan klasikal 91,42 yang berarti hampir seluruh siswa telah memperoleh nilai tuntas dengan 3 orang siswa yang belum mendapatkan nilai di atas KKM. Dengan demikian tindakan yang diberikan pada siklus II telah berhasil memberikan perbaikan hasil belajar pada siswa. Hal ini 
dipengaruhi beberapa faktor diantaranya adalah sebagai berikut:

a. Siswa sudah mulai terbiasa dengan bekerja secara kelompok.

b. Keberanian siswa untuk berinteraksi berjalan dengan baik karena siswa sudah mulai terbiasa untuk bertanya dan menyampaikan pendapatnya kepada sesama teman lainnya dalam menyelesaikan masalah.

c. Siswa mulai aktif dan tahu akan tugasnya dan berpikir secara kritis.

Pada siklus II, pelaksanaan pembelajaran inquiry training diberi tindakan berupa memberikan arahan kembali tentang model pembelajaran yang digunakan, dan memberikan motivasi kepada siswa.

Pada siklus II guru telah menerapkan model pembelajaran inquiry training dengan baik dan dilihat dari aktivitas siswa serta hasil belajar siswa pelaksanaan proses belajar mengajar sudah berjalan dengan baik. Maka tidak diperlukan revisi terlalu banyak, tetapi yang perlu diperhatikan untuk tindakan selanjutnya adalah memaksimalkan dan mempertahankan apa yang telah ada dengan tujuan agar pada pelaksanaan proses belajar mengajar selanjutnya penerapan pembelajaran dengan menerapkan model pembelajaran inquiry training dapat meningkatkan proses belajar mengajar sehingga tujuan pembelajaran dapat tercapai dengan maksimal.

\section{Pembahasan}

Berdasarkan hasil pelaksanaan pada siklus I dan II dapat dinyatakan bahwa terjadi peningkatan kualitas pembelajaran yang tampak dan perolehan hasil tes dan keaktifan siswa. Merujuk pada Gambar 2 dan Gambar 3 terjadi peningkatan aktivitas belajar siswa. Penilaian aktivitas diperoleh dari lembar observasi aktivitas. Pengamatan dilakukan oleh dua pengamat selama 20 menit. Dengan pengamatan setiap 2 menit. Merujuk pada Gambar 2, pada siklus I rata-rata aktivitas I yakni mempragakan 33\%, mengerjakan LKS 21\%, aktivitas bertanya pada teman sebesar $13 \%$, aktivitas bertanya kepada guru $13 \%$ dan aktivitas yang tidak relevan dengan KBM sebesar 22\%. Merujuk pada Gambar 3 pada siklus II aktivitas mempragakan naik menjadi $35 \%$, Sementara aktivitas mengerjakan LKS naik menjadi $24 \%$. Aktivitas bertanya pada teman naik menjadi $17 \%$ dan bertanya pada guru naik menjadi $19 \%$. Kesimpulan ini diperkuat dengan temuan bahwa Saptariani Br. Purba: Penerapan Model ..

menjaaı $0 \%$.

Dari data diatas dapat diambil kesimpulan bahwa terjadi peningkatan aktivitas belajar siswa dengan menerapkan model pembelajaran inquiry training selama KBM di kelas IV SD Negeri 101804 Gedung Johor. Hal ini terlihat dengan aktivitas mempragakan dari $34 \%$ menjadi 35\%, mengerjakan LKS dari $21 \%$ menjadi $24 \%$, bertanya kepada 
teman dari $13 \%$ menjadi $17 \%$ dan bertanya kepada guru dari $13 \%$ menjadi 19\% kegiatan yang tidak relevan dengan KBM dari $22 \%$ menjadi $6 \%$.

Merujuk pada tabel 2 dan Tabel 3, pada mata pelajaran penjaskes dapat kita lihat adanya persentase kenaikan nilai siswa dari pretes dengan rata-rata 60 dan ketuntasan $22,85 \%$ menjadi rata-rata 61,71 dangan ketuntasan klasikal $22,85 \%$ pada formatif I. Hal itu menunjukkan bahwa pelaksanaan siklus I belum mencapai keberhasilan. Formatif II menunjukkan adanya peningkata hasil belajar menjadi rata-rata 80 . Hasil siklus II dengan mendapatkan nilai rata-rata diatas $\mathrm{KKM}$, secara klasikal menunjukkan adanya keberhasilan pembelajaran dengan ketuntasan klasikal mencapai $91,42 \%$.

Secara keseluruhan hasil belajar siswa meningkat dari pretes, formatif I, sampai formatif II. Kesimpulan awal tentang karakter siswa adalah bahwa siswa tidak mempersiapkan diri untuk belajar di rumah tentang materi yang baru akan diajarkan di sekolah. Sehingga ketika peneliti melaksanakan siklus I, peneliti mengalami berbagai kendala antara lain ketika siswa berdiskusi dalam kelompok banyak kelompok yang terlihat bingung dalam pelaksanaannya. Ada pula yang bingung dengan langkah yang harus dilaksanakan. Sementara beberapa siswa tidak aktif dalam melaksanakan diskusi, siswa tersebut hanya berdiam diri, seolah-olah tidak mau tahu meskipun beberapa siswa aktif dalam berargumen. Kemudian ada beberapa kelompok yang masih bingung dan tampak belum bisa menarik kesimpulan diskusi.

Setelah merefleksi hasil-hasil pada siklus I maka dilakukan tindakan perbaikan pada siklus II dilakukan peneliti setelah melakukan refleksi di akhir siklus I dan berdiskusi dengan sejawat (guru mata pelajaran yang sama), dan pembimbing dari LPMP Sumut dan UNIMED. Tindakan yang dilakukan diantaranya:

1. Peneliti memberikan motivasi kembali kepada siswa diawal pembelajaran.

2. Peneliti menjelaskan kembali tentang model pembelajaran yang digunakan.

Peneliti memberikan tugas rumah tentang materi siklus II kepada siswa sebelum memasuki siklus II agar siswa memiliki cukup persiapan untuk mengikuti proses pembelajaran yang akan di lakukan.

\section{KESIMPULAN}

Setelah data-data tes hasil belajar siswa terkumpul kemudian dianalisis sehingga dapat disimpulkan antara lain:

1. Hasil belajar siswa dengan menerapkan Model Pembelajaran Inquiry Training, pada siklus I nilai rata-rata siswa 61,71 dengan persentse klasikal 22,85\% belum mencapai nilai KKM. Pada Siklus II nilai siswa meningkat menjadi 80 dengan persentase klasikal 
$91,42 \%$, telah mencapai nilai KKM Penjaskes.

2. Aktivitas belajar siswa dengan menerapkan Model Pembelajaran Inquiry Training, siklus I aktivitas mempragakan 33\%, mengerjakan LKS $21 \%$, aktivitas bertanya pada teman sebesar 13\%, aktivitas bertanya kepada guru $13 \%$ dan aktivitas yang tidak relevan dengan KBM sebesar 22\%. Siklus II aktivitas mempragakan naik menjadi 35\%, aktivitas mengerjakan LKS sebesar $24 \%$. Aktivitas bertanya pada teman sebesar $17 \%$ dan bertanya pada guru sebesar 19\%. Kesimpulan ini diperkuat dengan temuan bahwa aktivitas yang tidak relevan dengan KBM pada siklus II menyusut menjadi $6 \%$.

Setelah melakukan kegiatan belajar mengajar selama empat kali atau disebut dua Siklus maka perlu saran agar pengguna atau yang memanfaatkan model-model pembelajaran benar-benar bermanfaat sesuai dengn tujuan penelitian.

1. Untuk menerapkan model pembelajaran Inquiry Training sebaiknya siswanya maksimum 35 orang perkelas.

2. Untuk menerapkan model pembelajaran Inquiry Training di kelas sebaiknya mudah menyusun meja-meja siswa untuk mengefektifkan waktu untuk berkelompok.

3. Untuk menerapkan model pembelajaran Inquiry Training di kelas sebaiknya menggunakan media yang menarik bagi siswa.

\section{DAFTAR RUJUKAN}

Arikunto, S., (2002), Prosedur Penelitian Suatu Pendekatan Praktek. Jakarta: Rineka Cipta.

Joyce, Wheil, dan Calhoun. (2010). Model's of Teaching (ModelModel Pengajaran. Yogyakarta: Pustaka Pelajar.

Sanjaya, W. (2008). Strategi Pembelajaran Berorientasi Standar Proses Pendidikan. Jakarta: Kencana.

Sani, R.A. dan Sudiran. (2012). Meningkatkan Profesionalisme Guru Melalui Penelitian Tindakan Kelas. Bandung: Citapustaka Media Perintis. 